\title{
A STUDY OF 4 CASES OF DYSOSTOSIS MANDIBULOFACIALIS ARISED FROM A FAMILY
}

\author{
By
}

Yasuhiko HASHIMOTO, Keinosuke SAKASHITA and Hideo OKUYAMA, $T_{\text {AKaShi }}$ AINO, SANAE SHIMADA

From the Department of Otorhino laryngology Nippon Medical School. Tokyo (Director: Prof. Y. Hashimoto)

Of 17 persons of a family examined 4 patients demonstrated signs of Dysostosis] mandibulofacialis. Three patients of four were further complicated with palatoschisis, radio-ulnar synostosis and thumb flexion contracture. Two patients, (four ears) received tympanoplasty and were found to have a malformation of the middle ear (mastoid, tympanum and ossicles) without the evidence of inflammation. Domestic and foreign literatures concerning the disease with middle ear malformation and the methods of surgery were referred.

\section{一家系に生じた Dysostosis mandibulof acialis について}

$$
\begin{aligned}
& \text { 日本医科大学㷅舜咽喉科教室 }
\end{aligned}
$$

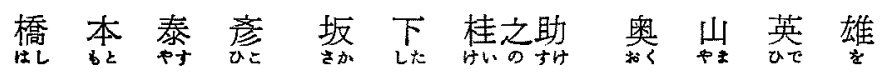

$$
\begin{aligned}
& \text { 愛野孝志島思思早苗 }
\end{aligned}
$$

\section{I 緒 言}

1846年 Thomson 1) が先天性に顔面下部の発育不全, 外耳中耳の変形㯖力障慧，四肢の奇形等が家族的に発生 した事記述し 1888 年眼科医 Treacher Collins 2) が 更K Colobome の所見を見出し Treacher-Collins syndrome と名付けた。

1944 年 Franceschetti と Zwahlen 3)はこれ等の症 状を更に克明隹察し Dysostosis mandibulofacialis と命名した，它の後，本矤患について諸外国及び本邦に おいての報告は数を增し外耳，中耳奇形については接極 的に改善手術を試みその全貌を明らかにするようになつ た.

さて我々は最近1家系に生じた本疾患について調查し たところ口蓋破裂や上肢の奇形を伴つた者もあり内 2 症 例化㯖力改善手術を行い中耳奇形の手術所見を得たので ここに報告する。

$$
\text { II 症例 }
$$

症例 1 半○加 $\left(B_{1}\right) 44$ 才
初診：昭和 39 年 11 月 5 日

主訴：難聴

家族歴：家系図（図1) に示すよらに患者の母，祖 母達には本症候群らしいものは見当らないが弟達，祖父 兄弟，智祖父兄弟には斜瞼㤠があるが（写真 1) 下颚骨 不全，難聴者はいない，又血族結婚はしていない，患者 は子供を5人分婏したが長女は症例 2 であり，長男は生 後 7 カ月目に肺炎で死亡し, 次女は未熟見で出産し 2 日 目死亡している，3女は症例 3であり，次男は症例 4 である(図 2).

既往厢：前述の3 人兄弟の長女であり出痤は正常， 幼少時より難聴があるだけで大きな疾患に罹つた事は ない.

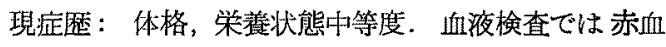
球 $394 \times 104$, 白血球 3400 ，血色意 $78 \%$ ，血清鉄 $90 \gamma /$ $\mathrm{dl}$ ，鉄結合能 $360 \gamma / \mathrm{dl}$ でありやや費血がある．その他 異常なし。

尿中ホルモン定量 $17-\mathrm{KS} 8.4 \mathrm{mg} / \mathrm{day}$, 正常值 3〜5 


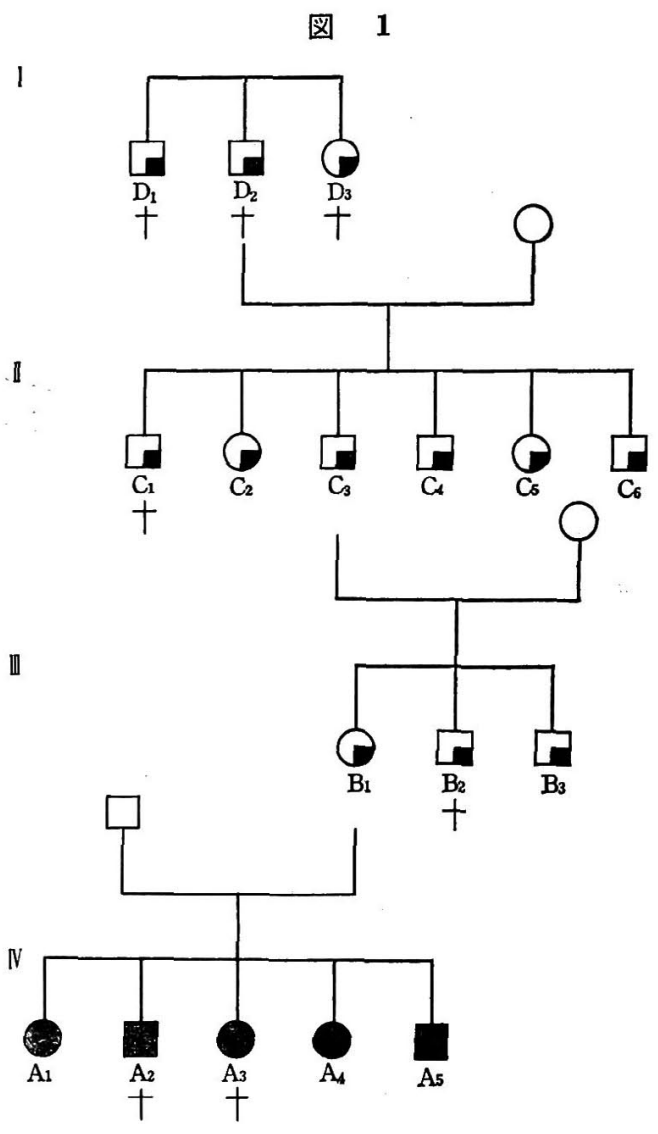

写真 1 症例 1 の弟と父. 臉裂が外下方に傾斜

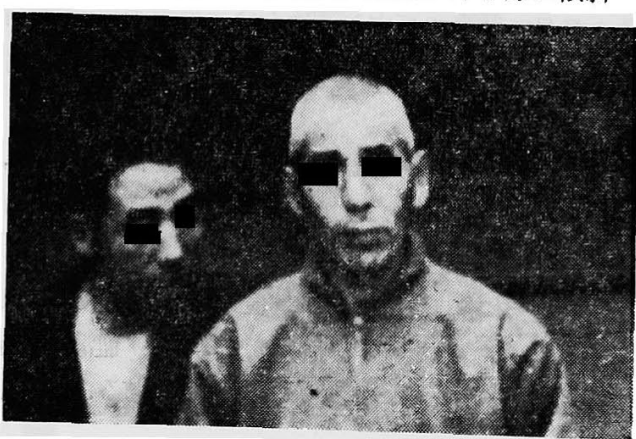

$\mathrm{mg}$ (多い), 17 OHCS $3.97 \mathrm{mg} / \mathrm{day}$ 正常值 $0.7 \sim 2.5$ $\mathrm{mg}$ (多い). $17 \mathrm{OHCS} 3.97 \mathrm{mg} /$ day 正常值 $0.7 \sim 2.5 \mathrm{mg}$ (多い). Estrogen $126.35 \mu \mathrm{g} /$ day 正常值 $5 \sim 30 \mu \mathrm{g}$ (多 い). Gonadotropin 48 単位以上正常値 $48 \sim 192$ 単位 (正常).

Pregnanediol $0.83 \mathrm{mg} / \mathrm{day}$ 正常值 $0.5 \sim 1.2 \mathrm{mg}$ (正 常）顔貌は口唇が大きいほか耳鼻咽䐅科所見では異常は ない（写真 2 の A, B). 聴力检査では両耳全周波数平 均聴力約 $26 \mathrm{db}$ の気導聴力損失があり（図3) 又四肢に 扣いて拇指末節屈曲拘縮がある。 


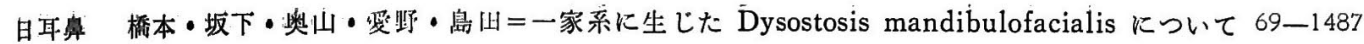

図 $\quad 2$

\begin{tabular}{|c|c|c|c|c|c|c|c|c|c|c|c|c|c|c|c|c|c|}
\hline \multirow{2}{*}{$\begin{array}{l}\text { Symtoms in } 16 \\
\text { Cases with d.m.f }\end{array}$} & \multicolumn{5}{|c|}{ 手術患者见弟 } & \multicolumn{3}{|c|}{ 母 兄弟 } & \multicolumn{2}{|c|}{ 祖 } & 父 & \multicolumn{3}{|l|}{ 兄 } & \multicolumn{3}{|c|}{ 薢祖父见弟 } \\
\hline & $\mathrm{A}_{1}$ & $\mathrm{~A}_{2}$ & $\mathrm{~A}_{3}$ & $\mathrm{~A}_{4}$ & $\mathrm{~A}_{5}$ & $\mathrm{~B}_{1}$ & $\mathrm{~B}_{2}$ & $\mathrm{~B}_{3}$ & $\mathrm{C}_{1}$ & $\mathrm{C}_{2}$ & $\mathrm{C}_{3}$ & $\mathrm{C}_{4}$ & $\mathrm{C}_{5}$ & $\mathrm{C}_{6}$ & $\mathrm{D}_{1}$ & $\mathrm{D}_{2}$ & $\mathrm{D}_{3}$ \\
\hline 頭 蓋 骨 変 形 & + & $?$ & $?$ & + & + & + & - & - & - & - & - & - & - & - & - & - & - \\
\hline 瞼 裂 傾 斜 & + & + & $?$ & + & + & - & + & + & + & + & + & + & + & + & + & + & + \\
\hline 下 眼 瞼 睷 毛 & 少 & $?$ & $?$ & 少 & 少 & - & - & - & - & - & - & - & - & - & - & - & - \\
\hline 先天性耳癄 孔 & - & $?$ & $?$ & + & - & - & - & - & - & $?$ & - & $?$ & $?$ & $?$ & $?$ & $?$ & $?$ \\
\hline 大 & + & + & $?$ & + & + & + & - & - & - & - & - & - & - & - & - & - & - \\
\hline 蓋破 & + & - & $?$ & - & - & - & - & - & - & - & - & - & - & - & - & - & - \\
\hline 不 整 歯 裂 & - & $?$ & $?$ & + & - & - & - & - & - & $?$ & - & $?$ & $?$ & $?$ & $?$ & $?$ & $?$ \\
\hline 下 顎 骨 不 全 & + & + & + & + & + & - & - & - & - & - & - & - & - & - & - & - & - \\
\hline 橈尺関 節 凂 合 & + & $?$ & $?$ & - & + & - & - & - & - & - & - & - & - & - & - & - & - \\
\hline 拇指 屈曲 拘 縮 & + & $?$ & $?$ & - & + & + & - & - & - & - & - & - & - & - & - & - & - \\
\hline 聴力 障、害 & + & $?$ & $?$ & + & + & + & - & - & - & - & - & - & - & - & - & - & - \\
\hline
\end{tabular}

\section{図３}

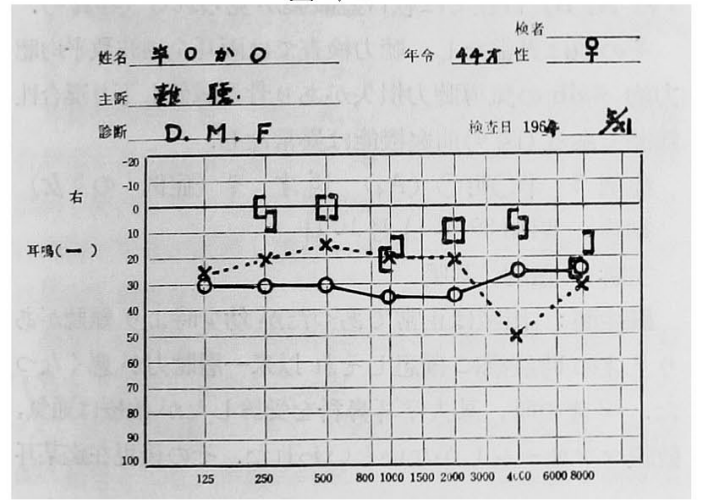

写真 $4 \mathrm{~A}$ 症 例 2

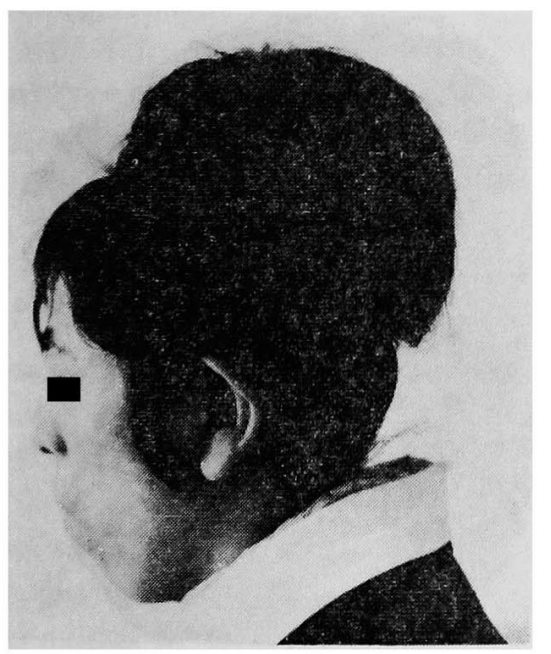

写真 3 症例 2 両橈尺関節猕合

回外回内運動制限 X印

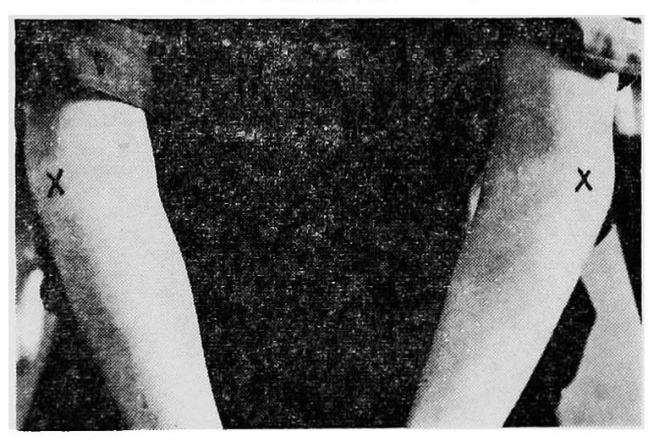

写真 $4 \mathrm{~B}$ 症 例 2

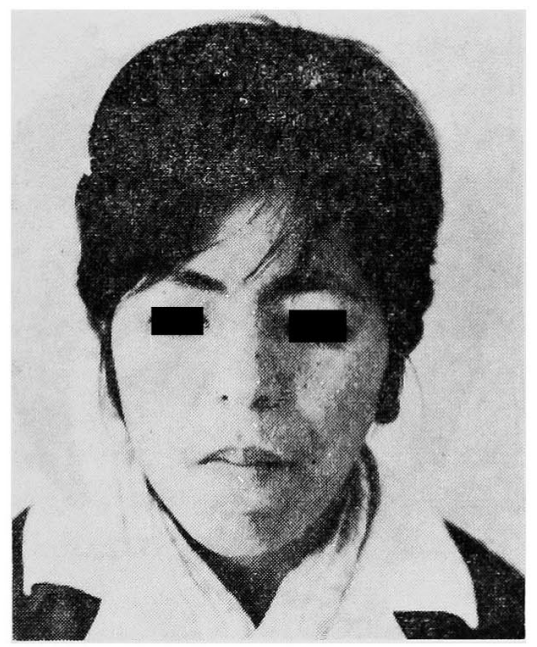


症例 2 半○和 $\bigcirc\left(\mathrm{A}_{1}\right) 20$ 才 $\quad$ (症例 1 の長女)

初診：昭和 39 年 12 月 22 日

主訴： 難聴と言語障害

既往歴：出産は正常であつたが難聴と口蓋破裂があ り急性中耳炎に度々䍜患し8才の時, 某大学口腔外科で 口蓋成形手術を受けている。

現症歴：体格栄養状態はやや不良，胸部腹部異常な ᄂ.

血液検查：赤血球 $388 \times 10^{4}$, 白血球 3900 , 血色素 量 $65 \%$ ，血清鉄 $80 \mathrm{r} / \mathrm{dl}$ ，やや賀血がある．その他異常 なし.

職業は女工であるが知能はやや低い，四肢に括いて上 腕の回外回内運動制限と 近位橈尺関節癒合 (写真 3) 及

写真 5 症例 2 口蓋破裂

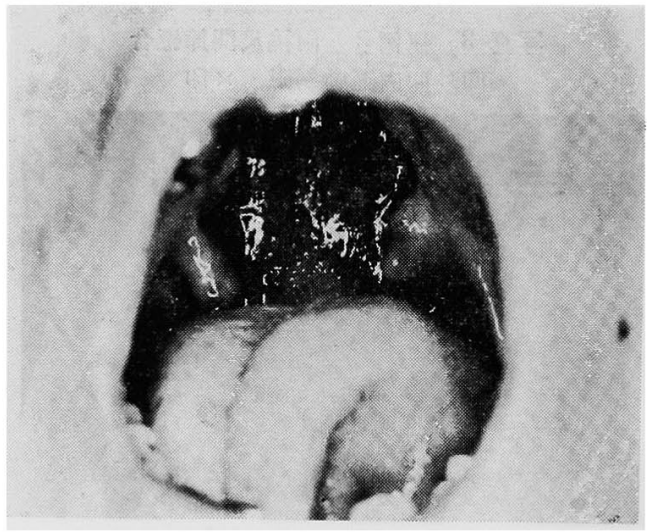

写真 6 A 症 例 3

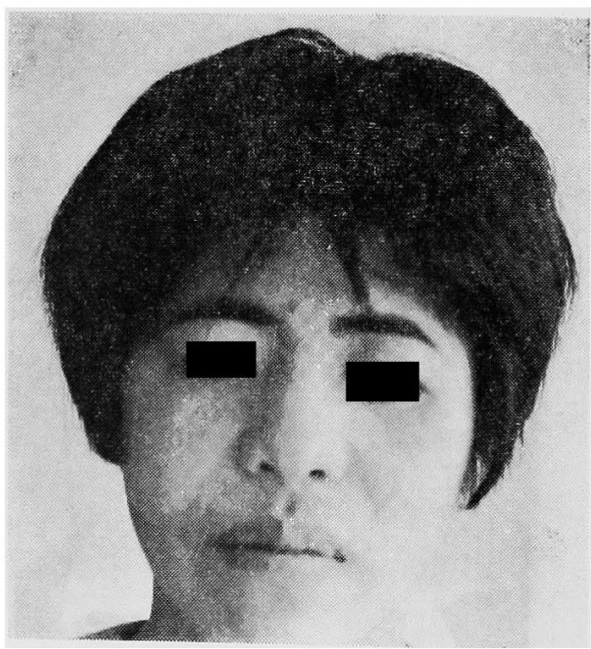

图 4

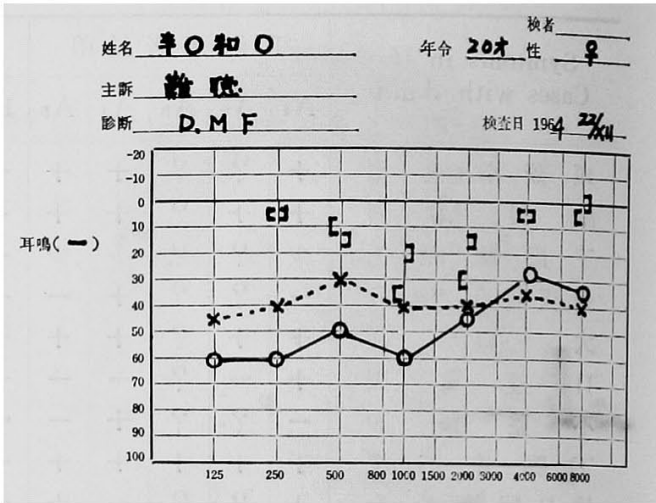

び拇指屈曲拘縮がある. 顔色は浅黒く左臉裂が外下方に 傾斜し (Antimongoloid 様) 啑毛は少ない，鼻根部の 陌凹が弱く下顎骨の狭少があり口唇はやや大きい（写真 4 の A, B) 口腔では軟口蓋破裂が見られる (写真5).

气の他は異常なし，聴力検查では両耳全周波数平均咕 力約 $40 \mathrm{db}$ の気導聴力損失があり骨導域値も下り混合性 難聴である (図 4) 前庭機能は異常なし.

症例 3 半O町 $\left(\mathrm{A}_{4}\right) 15$ 才 + (症例 1 の 3 女) 初診：炤和 39 年 11 月 10 日

主訴：難聴，耳鳴:

既往歴：出産は正常であつたが 幼少時より難㯖があ り 9 才の 時疫痢に 罹患しそれ 以来一層聴力が悪くなり た. 12 才の時, 某大学耳鼻科を受診したが 治療は通気、 鼓膜マッサージしかないといわれた。そとの後現在迄某耳

写真 6 B 症 例 3

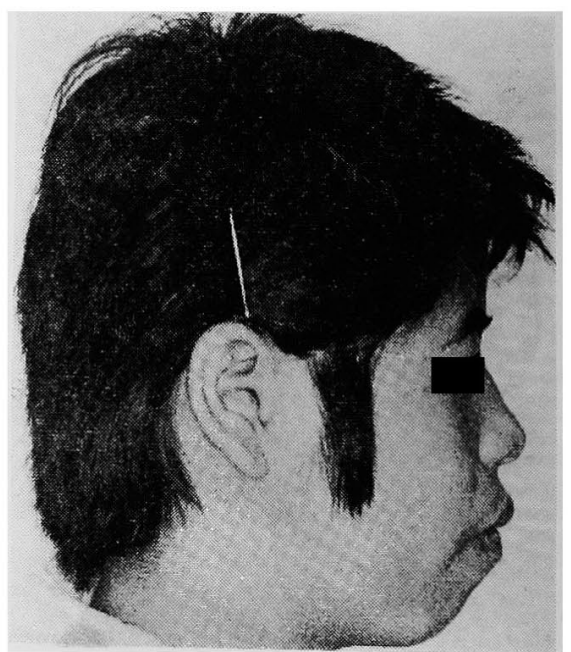


日耳厸橋本・坂下・奥山・愛野・島田二一家系に生じた Dysostosis mandibulofacialis について 69一1489

鼻科医で治療を受けていた.

現病歴：体格栄養状態は中等度. 胸部, 腹部は異常 なし.

血液検查：赤血球 $373 \times 10^{4}$, 白血球 5900 , 血色素量 $74 \%$ ，血清鉄 $103 \gamma / \mathrm{dl}$ ，やや賛血がある.

尿所見：糖, 蛋白は正常.

月経: 正常.

尿中ホルモン定量

17-KS 5.3mg/day (多い)

$17-\mathrm{OHCS} 2.58 \mathrm{mg} / \mathrm{day}$ (多い)

Estrogen $3.35 \mu \mathrm{g} /$ day (少い)

Pregnanediol $1.02 \mathrm{mg} /$ day (正常)

Gonadotropin 4 単位以下/day (少い)

その他異常なし. 家事を手伝つているが知能はやや遅 れている.

全身所見：顔色は浅黒く両瞼裂が外下方に 傾斜して いる. 下顎骨の狭少がある（写真6の A, B) 又口唇が 大きく (大口症) 不整歯列がある (写真 7).

耳鼻咽䐅科所見：両耳翼は正常であるが左右の耳瘻 孔形成が見られる (写真 8 ) 両外耳道はやや狭く鼓膜は 混濁し宿凹している. 耳管通気度は正常である．鼻腔で は両側下甲介が肥厚し膿咑が貯溜していた，咽喉所見で は異常を認めない。

顔面レ線所見では前頭骨·側頭面及び蝶形骨大翼の発育 不良と下顎骨の発育不全があり上顎洞は小さい（写真の ${ }^{9}$ A) 頭部側面像ではその外頭蓋骨は前後径が 短く後頭 部は扁平となり，頭蓋底は低い，トルコ鞍は深く前後径 の短縮がある (写真の ${ }^{9} \mathrm{~B}$ ).

耳のレ線所見 (Schüller 氏法) では乳様洞蜂窩の 発 育抑制と鼓室が小さい(写真 10).

聴力像は術前右全周波数平均聴力約 $60 \mathrm{db}$ ，左平均約 $50 \mathrm{db}$ の気導聴力の損失がある (図 5). 前庭機能は正常 であつた. 家族の希望もあり我々は聴力改善于術を試み たのである.

手術所見及び経過:

昭和 39 年 12 月 5 日 右豉室成形術施行

Spina supra moatum は增殖し大きく，その反面乳様 洞蜂简の発育は悪い，鼓膜を翻転し鼓室を開けると， 上鼓室は狭く Spina tympanica major 及び minor が 桘骨頭，砧骨頭と固着し槌骨の可動性はなく砧骨の長脚 は萎縮し蹬骨は久除していた．鼓室砧膜に炎症性肉芽組 織はなく，鼓室岬に点状の黒色色素が 1 つ見られた。

Chorda tymponi や M. tensor tympani は正常で
写真 7 症例 3 . 不整歯列

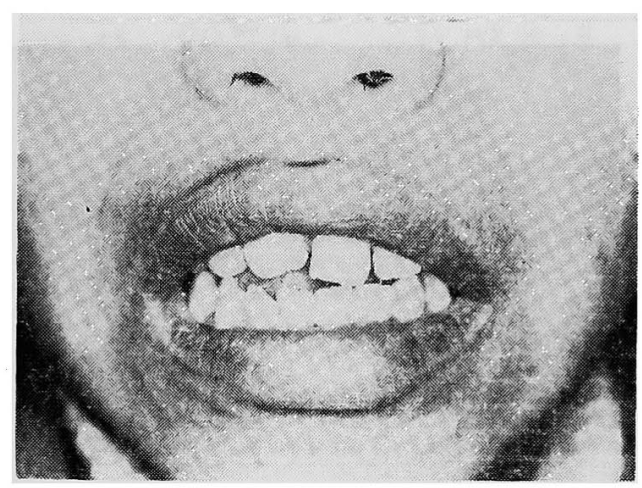

写真 8 症例 3 . 左右の耳㾔孔形成

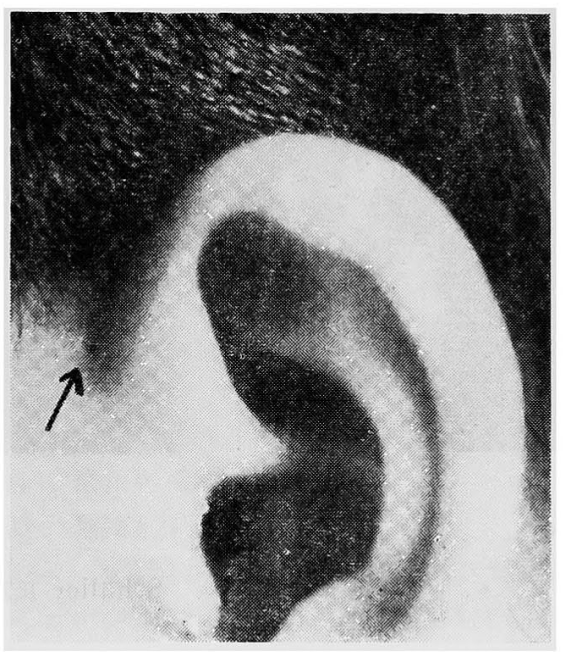

あつたが M. tensor stapedie はなかつた（写真 11).

Columella を桘骨長脚と卵円空との間に 接合しその 上Fasucia を当て耳後皮弁を植皮し術を終つた。術後 療法の他に，耳内笳及び耳小骨の鿒帯の代謝賦活の日的 で TTFD 150mg (Vit $B_{1}$ ) と Hydroxocobalamin $1000 \gamma\left(\mathrm{Vit} \mathrm{B} \mathrm{B}_{12}\right)$ を又造血促進する意味で硫酸鉄（Hematon） $4 \mathrm{Tab} 10$ 日間投与し耳内ガーゼは10日目 に除去したが本人は術前より聴えるようになつたとい 5 .

術後 1 力月目の聴力像では全周波数平均聴力約 $20 \mathrm{db}$ の聴力改善があつた（図 5)。しかし耳鳴は消失しなか つた．手術時採取した上鼓室の骨組織所見では骨組織は 軽度に增生しその周䢌に緸密な結合織が認められたが著 しい炎症機転は認められない（写真 12）. 
写真 $9 \mathbf{A}$ 症 例 3

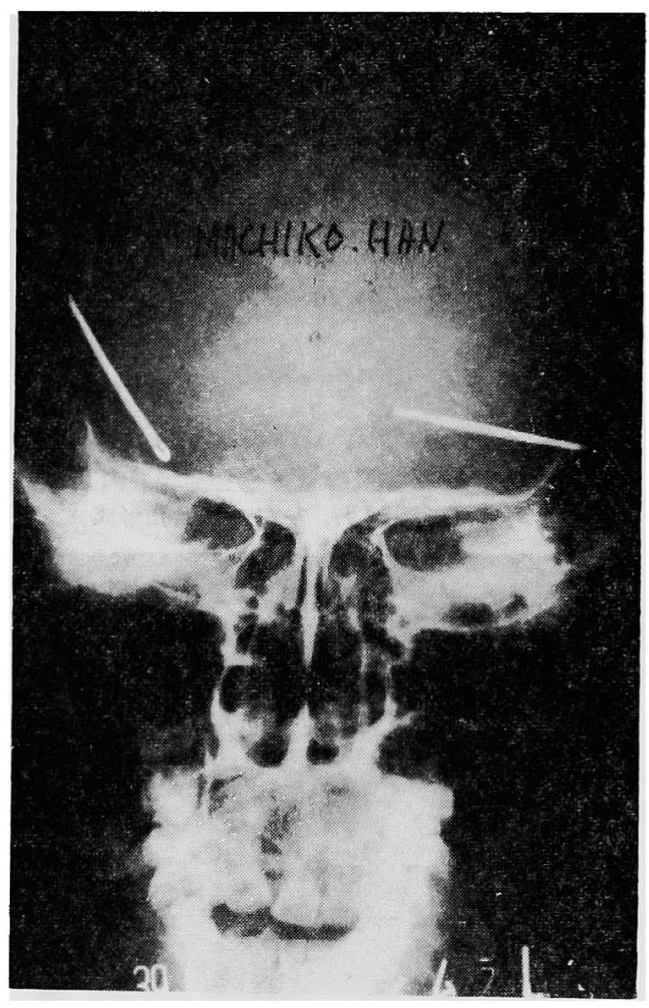

写真 10 症例 3. Schüller 氏法

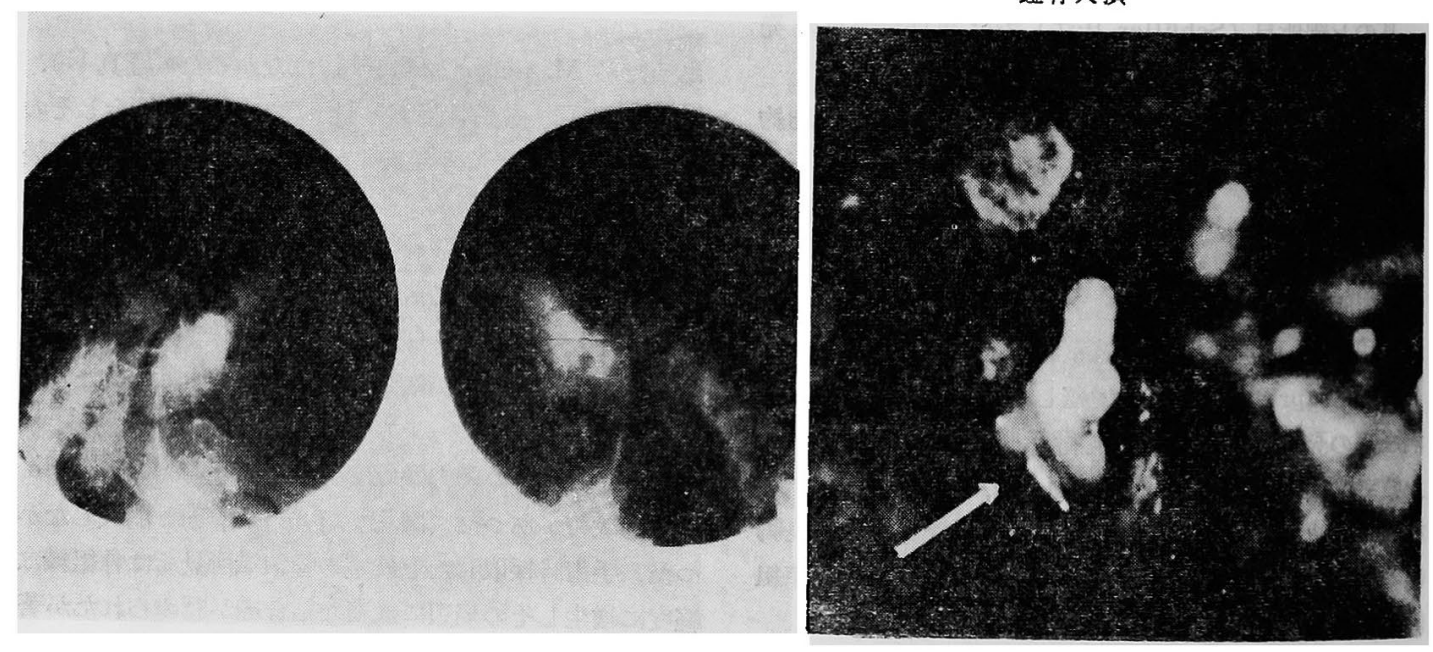

写真 $9 \mathrm{~B}$ 症例 3. トルュ鞍は深く前後径に短縮

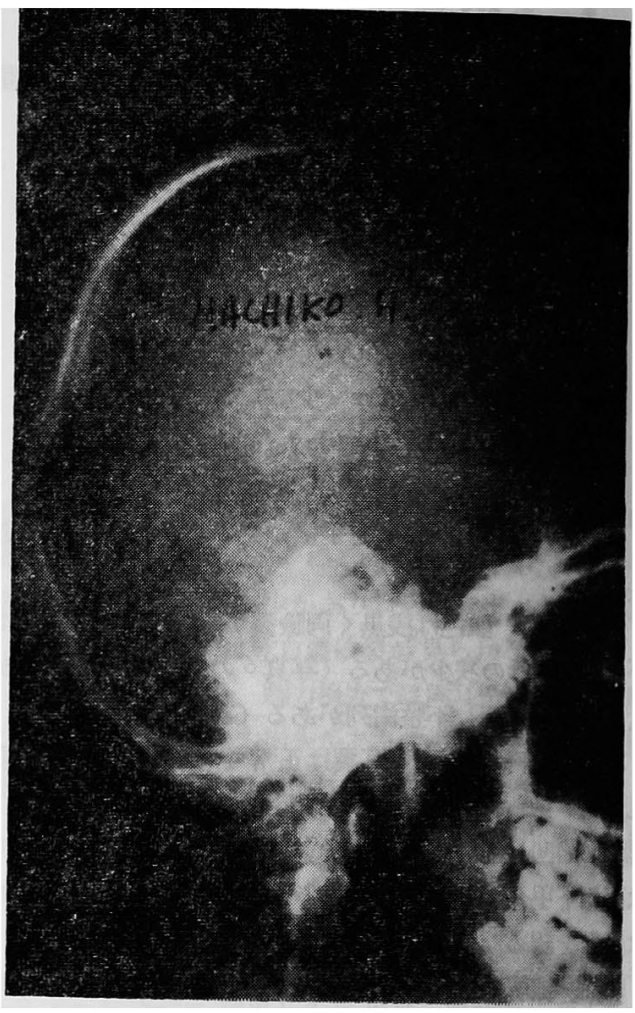

写真 11 症例 3.（鼓室成形手術所見） 鐙骨欠損 


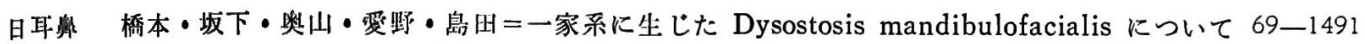

写真 12 症例 3. (左鼓室成形手術所見) 砧骨長脚は萎縮

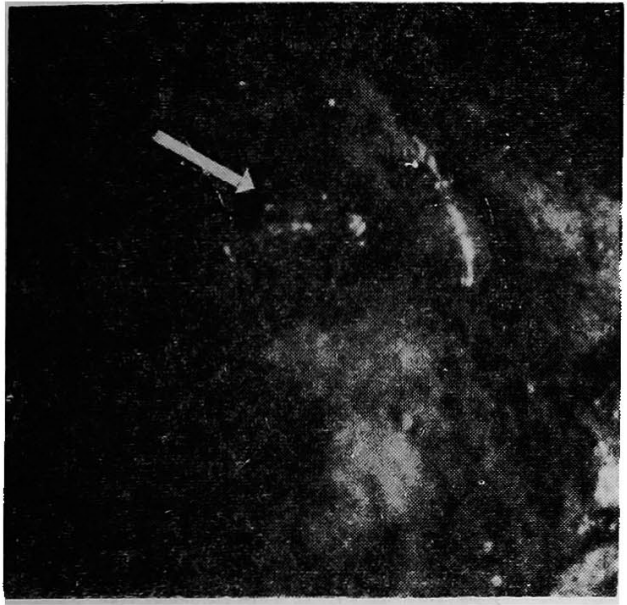

写真 13 症例 3,（右上鼓室骨組織） 非炎症性骨緻密構造を示す

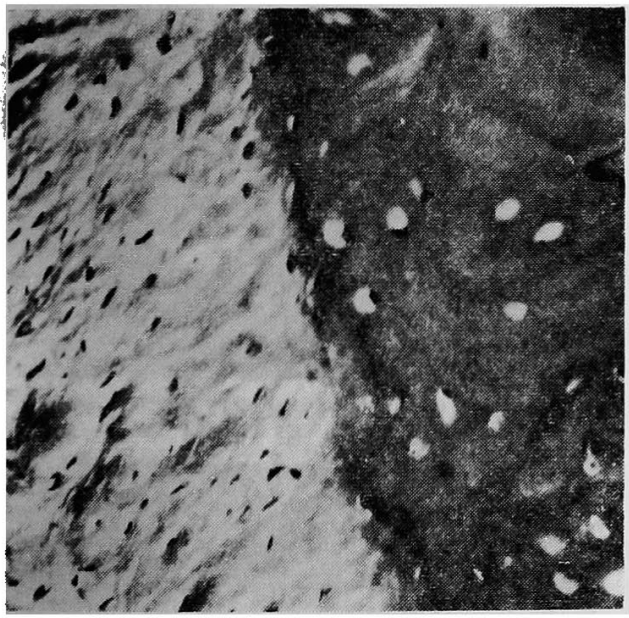

昭和 39 年 12 月 16 日 左鼓室成形術施行

右耳と同じく Spina supra meatum の增殖があり， 骨部外耳道は狭く乳様洞蜂窝の 発育はやや不良であつ た. 鼓室に入ると桘骨は正常の型をしているが砧骨長脚 及び鐙骨が萎縮していて砧鐙関節は退化して線維性の組 織に固き代えられていた，砧鐙関節を補強する意味で弾 力性接着版 (Biobond) を使用した。

耳小骨の固着はなく鼓室岬及び下鼓室は薄い粘膜で被 われていた（写真 13).

術後右耳と同じ処着をした，術後 40 日目の 聴力像で
図 5

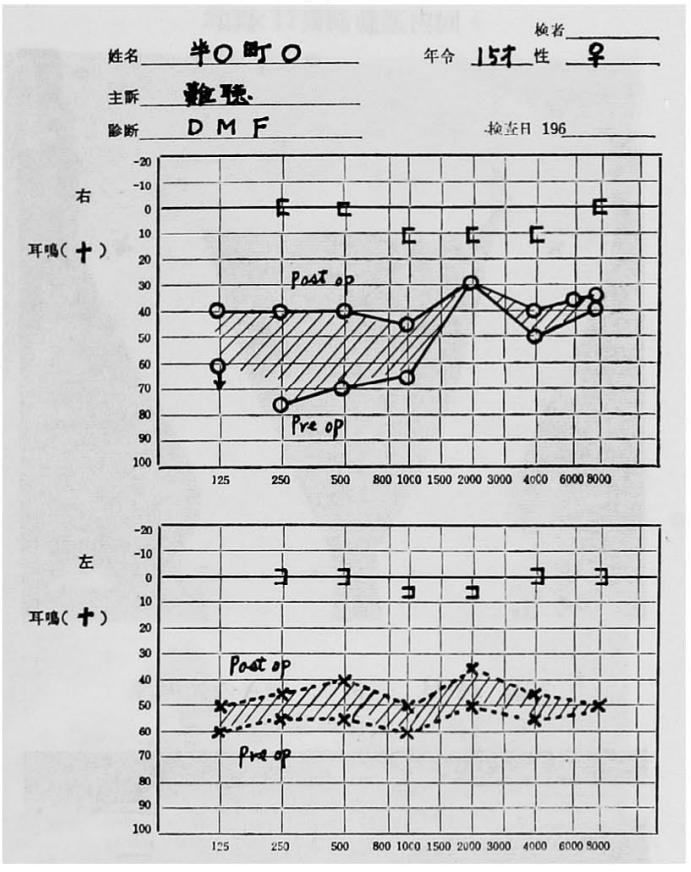

は全周波数平均聴力約 $10 \mathrm{db}$ の聴力改善があつた（図 5) 耳鳴は消失せず.

症例 4 半 $\bigcirc$ 豊 $\left(A_{5}\right) 11$ 才 (症例 1 の次男)

初診: 昭和 39 年 11 月 10 日.

主訴：難聴と耳鳴;

既往症：4 傾より両耳難聴に 気付き，言語か゚ 話せ ようになつたのは 6 才過ぎてからで知能は少し遅れてい る.

現症歴：体格は小さい方で栄養状態はやや不良，胸 部腹部は異状なし，血液検查では，ききわけがないので 充分採血ができず血球検査は不明，血清 P は $4.6 \mathrm{mg} / \mathrm{dl}$ 少し高値でありその他は異常なし.

尿所見：糖，蛋白正常

尿中ホルモン定量

17-KS $1.01 \mathrm{mg} / \mathrm{day}$ (正常)

17 -OHCS $2.04 \mathrm{mg} /$ day (多い)

Estrogen $7.3 \mu \mathrm{g} / \mathrm{day}$ (多小)

Pregnaediol $7.25 \mathrm{mg} /$ day (多い)

Gonadotropin 24 単位以下/day（多い)

小学 6 年生であり学校の成績は数学は少し良いが他の 課目は悪い。

全身所見：所謂掹で肩で症例 2 と同しくく上腕の 回外 
69-1492 橋本・坂下・奥山・愛野・島田二一家系に生じた Dysostosis mandibulofacialis にっいて 日耳鼻

写真 $14 \mathbf{A}$ 症例 4 . 両橈尺骨関節瘾合. 回外 回内運動制限 $\times$ 印

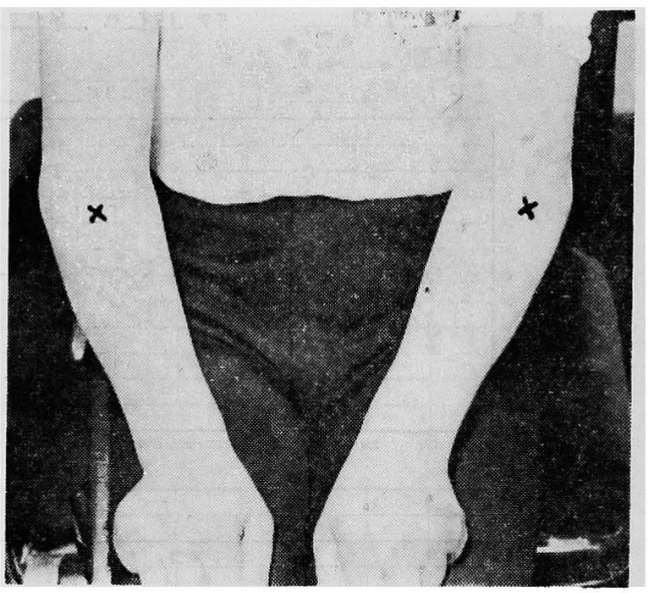

写真 $14 \mathbf{B}$ 症例 4.14 A 2 X線像 矢印 $=$ 疮合部

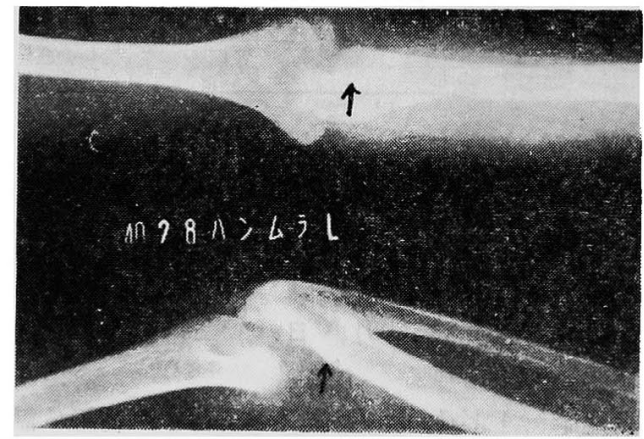

写真 $16 \mathbf{A}$ 症 例 4

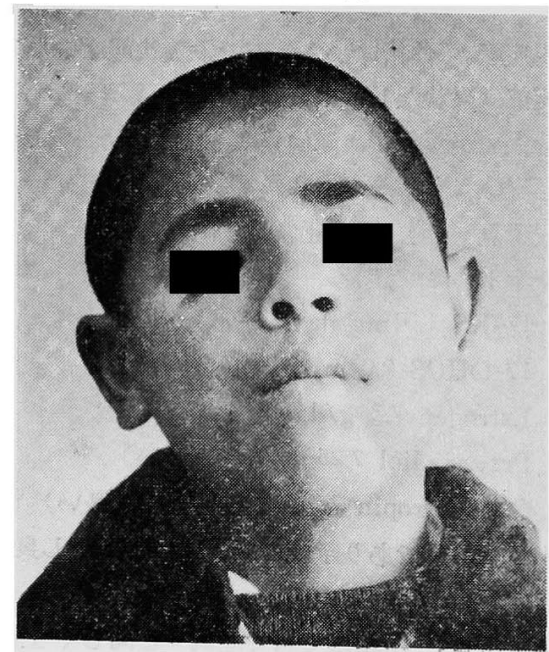

回内運動制限（写真 ${ }^{14} \mathrm{~A}$ ) 近位橈尺関節瘳合（写真 14 $4 \mathrm{~B}$ ）があり文右拇指屈曲拘縮（写真 15）が見られる. 顔色は赤黒く顔貌は母親及び兄弟の中で一番特徴を明ら かにしている.

即ち両眼瞼裂が外下方に傾斜し両眼隔離があり眼窩上 縁の発達が悪く下眼臉が四み睫毛は少ない，鼻根部の陌 凹が弱く下顎骨が狭少でで 口唇が大きい(写真の $16 \mathrm{~A}$ B).

\section{耳鼻咽喉科所見：}

両耳翼は正常で外耳道は狭小で屈曲している．鼓膜は 混濁乙宿凹している.耳管通気度は右は良好で左はやや 悪い. 鼻腔では両側下甲介がやや肥厚しているが, その 他咽喉頭所見は異常を認めない，前頭骨側頭面及び蝶形 骨大翼の発育不良と下顎骨に著しい発育不全があつた.

写真 15 症例 4 . 右拇指屈曲拘縮

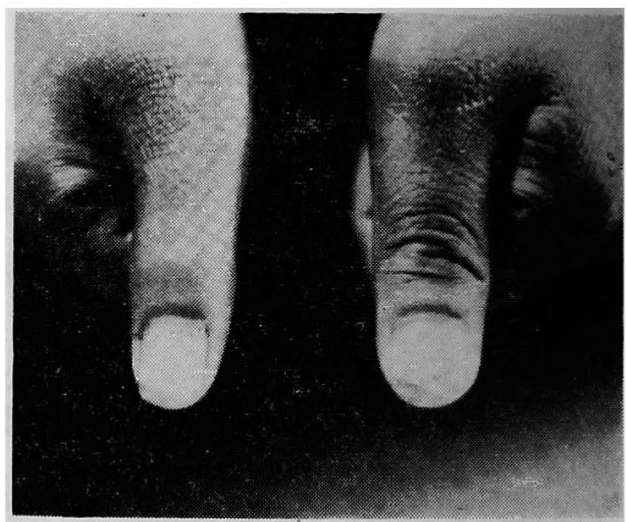

写真 $16 \mathrm{~B}$ 症 例 4

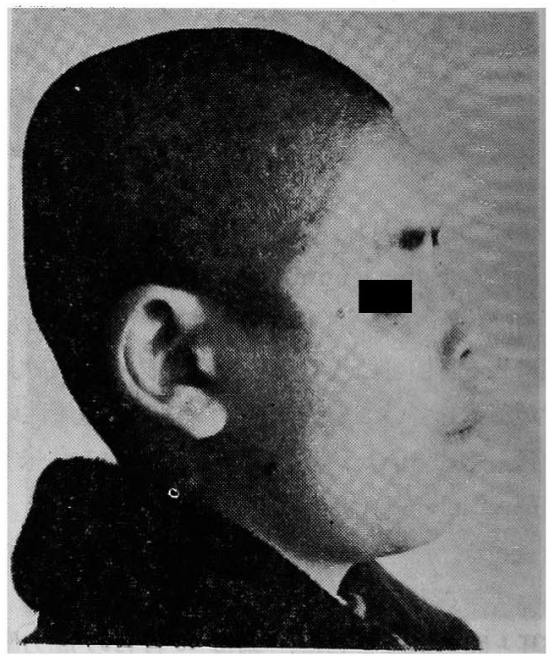




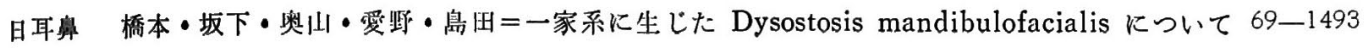

写真 17 A 症 例 4

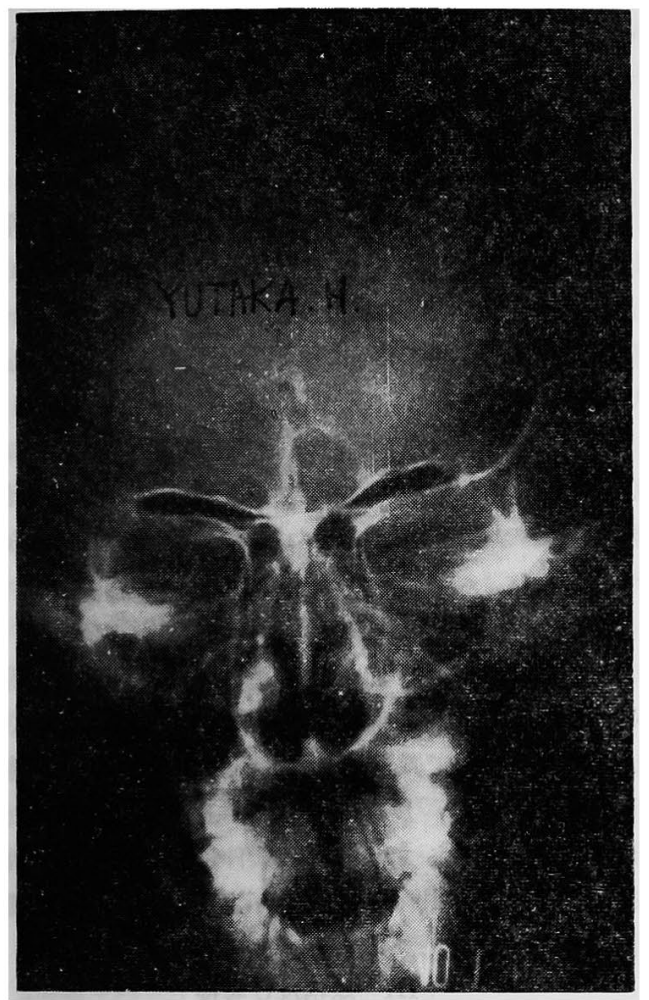

写真 18 症例 4. Schüller 氏法

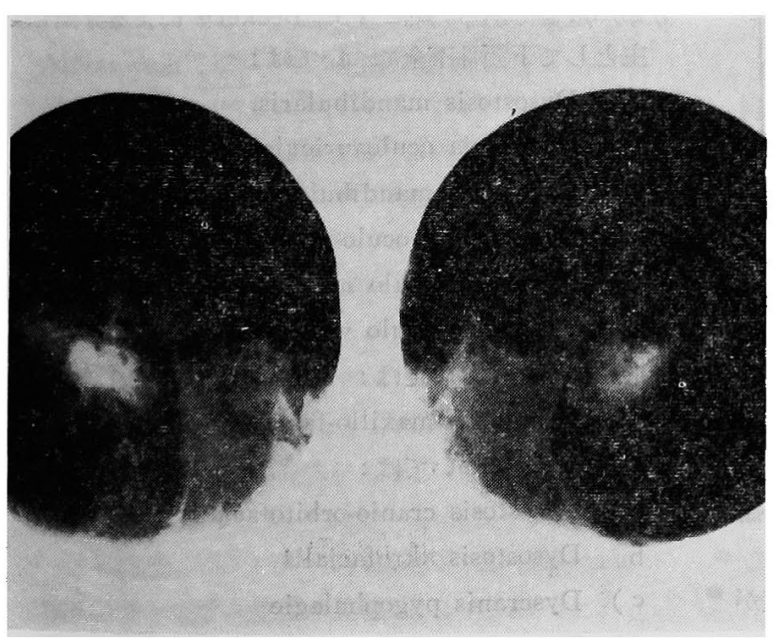

写真 $17 \mathrm{~B}$ 症 例 4

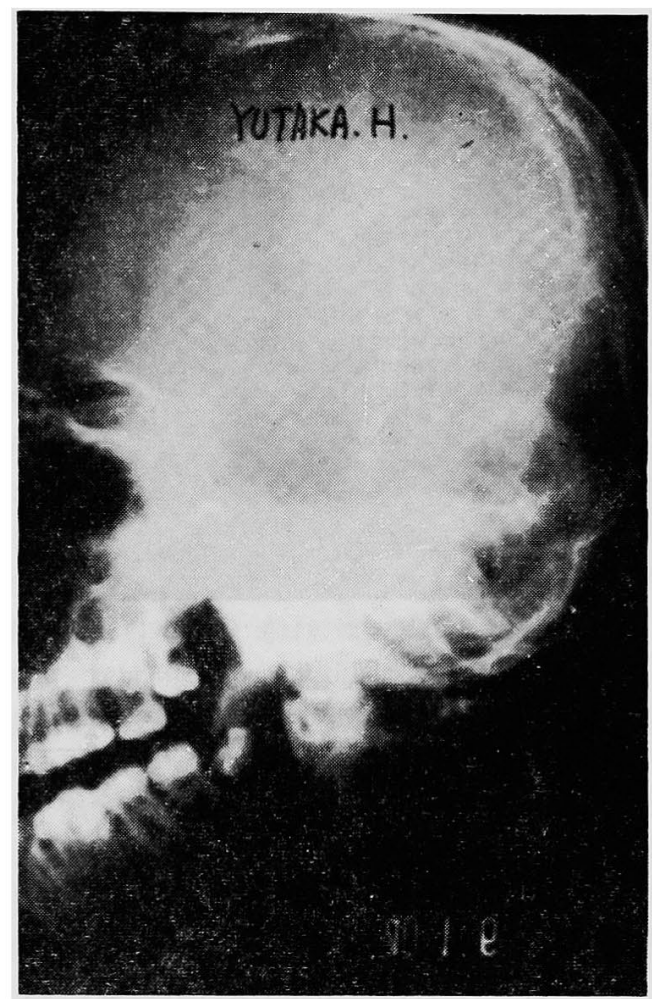

写真 19 症例 4.（左鼓室成形手術所見） 砧鐙関節は線維性組織である

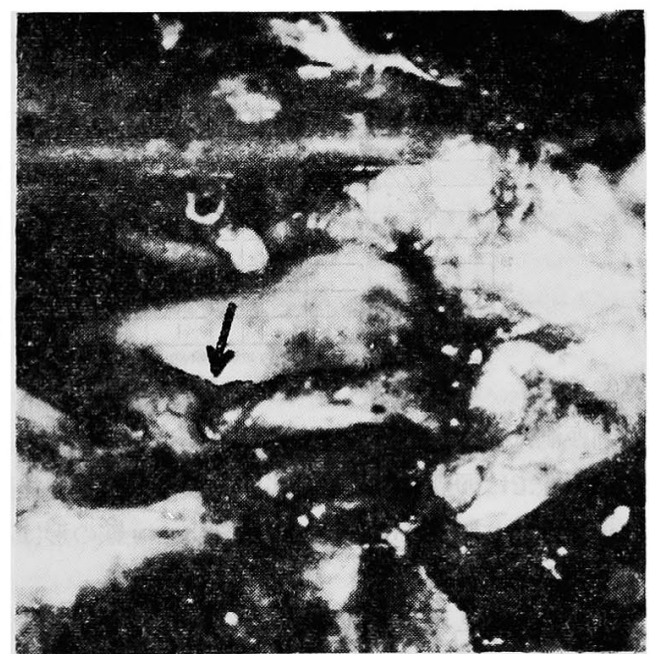


写真 20 症例 4 . (右鼓室成形手術所見) 砧骨長脚は細い線維性組織で置き代えられている

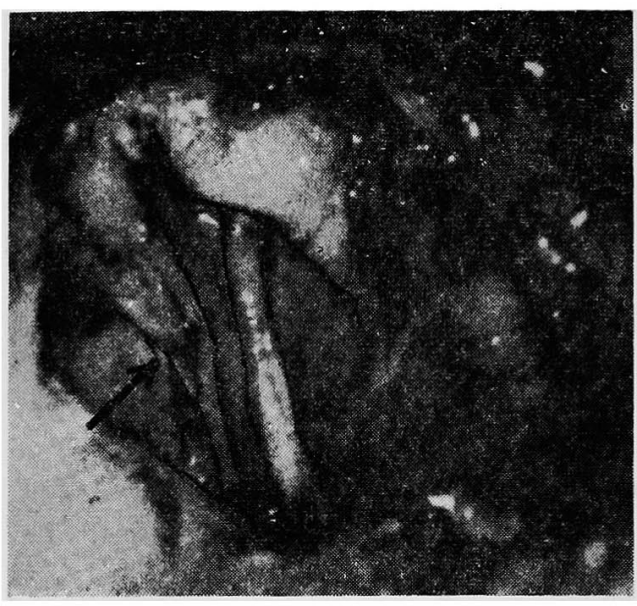

图 6

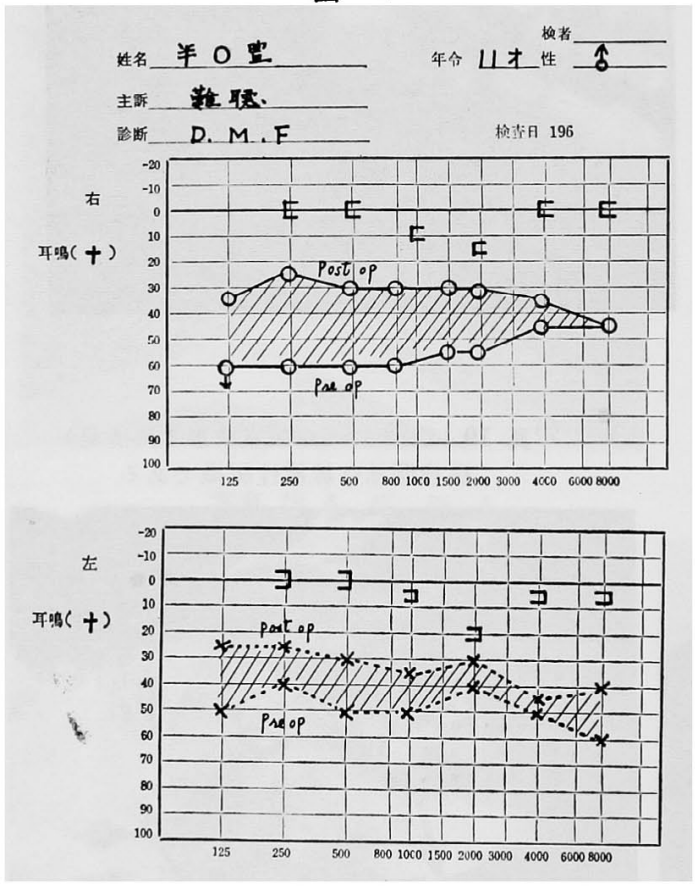

左前頭洞は大きいが両上顎洞は小さい(写真 $17 \mathrm{~A})$. 頭 部側面像では頭蓋骨は前後径が短く横径が延長し後頭部 は扁平·であり頭蓋底は低い，その外トルコ鞍の形は不鮮 明である (写真 17 B).

耳のレ線所見 (Schüller 氏法) では乳様洞と鼓室が 小さく蜂䈑の抑制がある（写真 18）.
聴力像は術前右全周波数平均聴力約 $55 \mathrm{db}$, 左平均 33 $\mathrm{db}$ の気導聴力損失がある (図6). 前庭機能は正常であ つた．症例 3 の姉の聴力改善手術が結果良好であつたの で本症例にも鼓室成形手術を行つた。

手術所見及び経過

昭和 40 年 1 月 18 日 左鼓室成形手術施行

本人はききわけがないので全身麻䣲で行つた. 槌骨頭 は上鼓室と固着していたので Spina Jympanica major 及び minor を削除し槌骨関節の骨連鎖を良好にした. 砧鐙関節は線維性のもので置き代えられ鐙骨は萎䑿して いた。

正円空は正常で鼓室粘膜，その他病的所見はなかつた (写真 19). 術後 15 日目の聴力像では 全周波数平均㯖力 約 $20 \mathrm{db}$ の聴力改善があつた (図6). 耳鳴は消失しなか つた.

昭和 40 年 2 月 2 日 右鼓室成形手術施行

左耳と同じく鼓室は狭小で砧骨頭は上鼓室と固着， これを削除した．桘骨関節の砧骨長脚は可動性は悪く細 い線維性のもので置き代り発育不全の小さな鐙骨と連鎖 していた (写真 20). これを弾力性接着刜で強化した. 鼓室腔は正常であつた。術後 14 日目の聴力像は全周波 数平均聴力約 $16 \mathrm{db}$ の聴力改善があつた（図6). 耳鳴仙 消失せず.

\section{III 紷括及び考按}

頭部顔面及び軀幹四肢等の先天奇形を伴 5 もの関し ては解剖学者, 整形外科医, 眼科医, 耳鼻科医によつて 古くから報告されている. 即ち R. Grimaud, P. Mounier-Kuhn ${ }^{37)}$ 他, P.E. Becker 等の臨床的及び病理的 分類が重要である.殊に P.E. Becker4)による分類では 主として下䫈骨不全については:
a) Dysostosis mandibularis.
b) Dysphasia oculoauricularis
c) Dysostosis mandibulofacialis
d) Dysmarphia oculo-mandibulofacialis
e) Dysphalia oculo mandibulofacialis
f) Dysphasia aculo vertebralis 上顎骨不全については：

Dysostosis maxillo-facialis を入れ 頭蓋骨不全については :
a) Dysostosis cranio-orbitofacialis (Crouzon)
b! Dysostosis akrofacialis
c) Dyscranis pygophalagie
d) Dysostosis cleidocranialis etc. があるが我々 


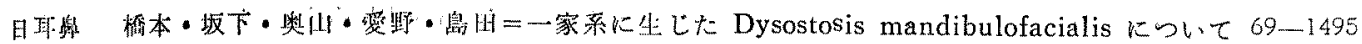

の应例で江上疑骨不全を伴 5 ので Dysostosis maxillo facialiskも入れる事がでさる。

発生学的には発生初期に和ける中䐤葉性骨原基の先天

異常であると云われている。

この中で最も耳鼻科记関係の深い.Dysostosis mandi bulo-facialis Kついての報告は Franceschetti u. Klein ${ }^{5}$ に上れぱ、Thomson (1846) 1) から始むつて 1958 年迄 150 例の症例が報告されたと述べている。

Berry (1888) 6), Treacher Collins (1900) 2), Morlinglaus (1955) 》) 等性脊椎，四肢，胸部にす変化があ り横湢膜の欠損もあつたと報告し，Franceschetti ${ }^{22}$, Granrad (1953) 8), Wieland (1954) 9), Pavsek(1958) 10), Plester (1961) 11) 等は副鼻腔にも異常があつたと 報告している: 手術例としては Alfaxelsson (1963) 2) 等は 2 家挨 10 例火中耳奇形を伴つたるのに，鼓室成形 手街を行つている、一方本邦に执いては次の報告がある。

口蓋貱裂顏面横裂，重唇を伴つたものう黒住等(1956)

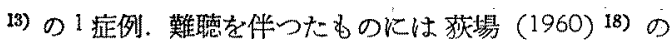

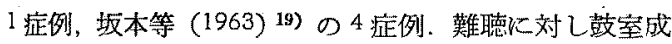
形術を行つたものKついて㤌大和田等 (1957) 14) のl症 例，広戸等 $(1965)^{15)}$ の 2 例症，鈴木等 (1965) 16) の 1 症例や中村等 (1960) 17) の1 症例がある.

本症候群の中耳奇形について最近聴力改善手術が盛ん になり以下のような諸外国の報告がある。

䇝骨，砧骨奇形心ついて

Livingstone (1958) 20) 水平半規管内耳閏空術

Fernandez (1958) 21 ) 後半規管内耳開空術 鼓室成形術 III N 型

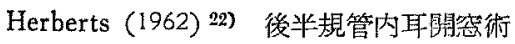

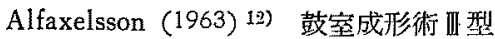

鐙骨奇形について :

Rüedi (1954) 23), Altmann (1955) ${ }^{24)}$, Harrisrn (1957) ${ }^{29}$, Plester (1961) 26), Alfaxelsson 1:2).

鐙骨脚奇形炕ついて:

両脚 Halbokow (1961) 27) 鼓室成形術 III 型

片脚 Fernandez ${ }^{21)}$

欠損 Makenzie (1958) ${ }^{28)}$

内年奇形 Frances chetti (1859) 29)

本邦に顿いては次の報告がある。

柢骨砧骨の奇形飞ついては：

大和由等 (1957) 14) Tympono stapediopexie

舵骨砧骨の奇形と鐙骨の欠損については：

中村等 (1960) 17) 鼓室成形汸
䊚青鐙骨の奇形と砧骨の久損については：

広戸等 (1965) 15) 鼓室成形術 III 型

以上の上5に3 うの耳小骨が共炕同じ奇形が起らない のは椎骨砧骨の発生原基仗第 1 腮马の Meckel's Cartilage から発生し鐙骨のそれは第 2 諰弓の Reicherti's Cartilage から発生しそれそれれ異つた発生起点によるす のであるら.

ここで中耳奇形性乳様洞鼓空腔の発育不良と耳小骨の 奇形，それ《伴与骨連鎖異常等があるが高原等 (1965) 30) 恃，外耳道之耳小骨の奇形の関係について外耳道正 常例に桘骨奇形はなく㫊骨”奇形も稀であるが鐙骨奇形は 殆えどに見られたと述べている，我々の症例について子 これと同じよらな所見であつた。

本症侯群の環境的要因について Roussel (1951) 31), Grünvall (1953) 32), Hunt (1955) 33), Harrison 25), Herbert (1962) 22) 等仕妊娠初期の外的要素が閔係し熱 疾患，機找的損傷，放射線障玫，酸素久泛，中毒症，栄

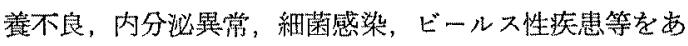
げ Granrad 9) は久の他受精卯の染色体異常羊膜の癒

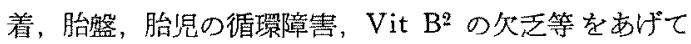
いる，我々の症例について要因と考光られるものは本症 例の一家系が茨木景の 1 寒村に代々定住し，親子等は戦

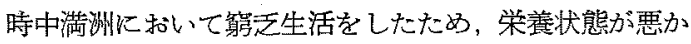
つたのも関係していると考えられる。

血液検查では本症例では頚血上血清鉄がやや低いが， 妊娠中の貧血飞ついては伊藤 (1964) ${ }^{34)}$ は下層階級及 莱食主娀者に多いと述心，古賀 (1964) ${ }^{36)}$ は奇形胃の

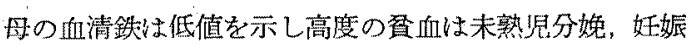
中毒発生，出産児の奇形発生があると述べている。

㕛骨の発育と内分泌比つ住性 腺ホルモン。副腎皮質ホルモン。卵胞ホルモン，黄体ホ ルモン，性腺刺钱ホルモン等）が骨の新陳代謝に及ぼす のであるが26) 本症例では Steroid Hormone の排泄量 か゚高値を示しトルコ鞍の变形があつたがこれらを考へ合 わセると興味深いのであるが奇形発生機転は複雑多様で 究明は甚だ困孉なるのか゚多い。

Franceschetti ¿ Klein ${ }^{5}$ は Dysostosis mandi* bulofacialis について混合した将態を分析し Complete form, mcomplete form, abortive form, unilateral form, atypical form に分けているが，本症例は世代が 変るに従い，病像が著明となつたもので症例 1 や症例 3 のような incomplete form では難㯖を主体とした患者 は本症候群上診断する棑性難しいが，難㯖に詨して今後 
聴力改善手術, 薬物療法, 理化学的治療等一層の進歩発 展が期待される。

\section{IV 結語}

1. Dysostosis mandibulofacialis 症候群 が続発 し た一家系を調査し 2 症例に鼓室成形術を行い中耳奇形を 探索し㯖力改善が得られた。

本症候群について文献的考察を加古遗伝型式環境的要 因及び症候群の分類症像等を述べ中耳奇形, 聴力改管手 術, 治療面等について本症例と比校検部した。

\section{引用文献}

1) Thomson, A.: Mth. J. Med. Sci, $7: 420,1864$. 2) Collins, E.T.: Case with Symmetrical congenital notches in the auter part of each lowerlid and defective development of the malar bones Trans. Ophth. Soc, 20: 190, 1900.

3) Franceschetti, $A$. \& Zwahlen, P.: Bull. Academie Suisse des sciences medicales. 1:60,1944. 4) P.E. Becker: Humangenetick Einkurzes Handbuch in fünf Bänden Band II 54, 1964. 5) Franceschetti, A \& Klein, D.: The Mandibulofacial Dysostosis a new hereditary Syndrome, Acta Opth. 27: 143, 1949.

Berry, G.A.: Note on congenital defect(Coloboma) of lower lid, Roy London Opthal hosp Rep 12: 255, 1888. 7) Morlinghaus, J.L.: Inaug. Diss (frankfurt) 1955. $\quad$ 8) Granrud, H.: On Etiology of Dysostosis Mandibulo-Facialis, Acta Paediat (Stockholm) 42: 499, 1955. 9) Wieland, H.: Laryngo, 33:739. 10) Pavsek, E.J.: Mandibulofacial Dysostosis (Treacher Collins Syndrome), Amen J. Roentgen 79:598, 1958. 11) Plester, D.: Acta Oto-laryng (Stockh) 53:55, 1961. Alf Axelsson: Dysostosis mandibulo-Facialis, The J of Laryng and Otolog 77: 7, 575, 1963. 13) 黒 住静之他：特異な口盐破裂顔面横裂乘唇を伴うTrea-

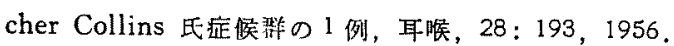
14)大和时健次郎他：聴力增進手術を行つた耳小骨奇 形を伴党る Dysostosis mandibulofacialis 01 侧,

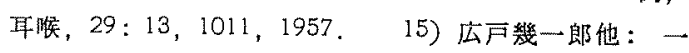
家系に多発せる Treacher-collins 㱏候群，日耳会，68， 6,787，1965. 16) 鈴木安恒他: Dysostosis mandibulobacialis, 日耳会, 68:12, 1952. 17) 中村四 郎他：両側鼓室小骨の奇形を伴つた Treacher Collins Syndrsme の 1 例, 耳㮢, 32:11, 957, 1960 .
萩場芳崔: Treacher Collins-Franceschetti 氏昰俣 の 1 例, 耳㬋，32：12，1055，1960，19）坂本伸郎他：家族的にみられたDysostosis mandibulofacialis 94 症例, 耳喉, 35:7, 555，1963. 20) $\mathrm{Li}$ vingstone, G.: Establischment of sound conduction in congenital deformiss of external ear, J Laryng, $73: 23,1958 . \quad 21)$ Alexis, O. Fernandez: The Treacher Collins Syndrome, Arch of otolaryng, 80 , Uov, 505, 1964. 22) Herberts, G.: Otological observations on Treacher Collins Syndrome, Acta Otolaryng 54: 457, 1962. 23) Ruedi, L.: Laryngoscope (St. Louis) $64: 666,1951$. 24) Altmann, F.: Ann, Otol (SA. Louis), 64: 824, 1955. Harrison, S.H.: Treacher Collins Franceschetti Syndrome, J. Laryng 71: 597 (Sept), 1957. 26) Harrison, S.H.: Treacher Collins Syndrome, Bri ${ }^{t}$ J Plast Surg 3: 282, 1950. 27) Halborow, C.A,; Deafness and Treacher Collins Syndrome, J Laryng 75: Nov 978, 1961. 28) Mckenzie, J. and Graig, J.: Mandibulo Facial Dysostosis (Treacher Collins Syndrome). Arch Dis child, 30, 1955. 29) France schetti, A. and Brocker, J.E.W.: Schweiz med. Wschr, 89: 478, 1959. 30) 高原流夫他: 聴器公音 系の先天性奇形に対与る手術的療法之胎生学的益察につ いて，日耳会，68：6，1966。 31) Roussel: Ann oculist (Paris) 184: 788, 1951. 32) Grön Vall, H. and Olsson, Y.: Acta ophthal (Kbh), $31: 245$, 1953. 33) Hunt, P.A. and Smith, D.I.: Pedia-

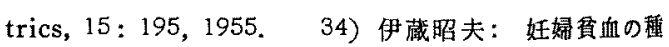
類，頻度扣よび診断，産嫃人科の世界，16:8,55, 1964. 35）古賀康八郎：娃婦貧血の母児に及活寸影 響, 児の奇形発生との関係，産婦人科の世界，16:2， 195, 1964. 36) Martin silberberg: Steroid Hormones and Bone, The Biochemistory and physiology of Bone, 623. $\quad 37) R$. Grimaud: Societe Francaise D'. Oto-rhino-Laryngologie, 94, Paris Librairie arnette 1962.

本論文の要旨は日本耳奥咽喉科学会関東地方会第 47 回大会に招いて発表した。

（原稿到着 $=$ 昭和 41.3 .4 日） 